Leonard ŁUKASZUK*

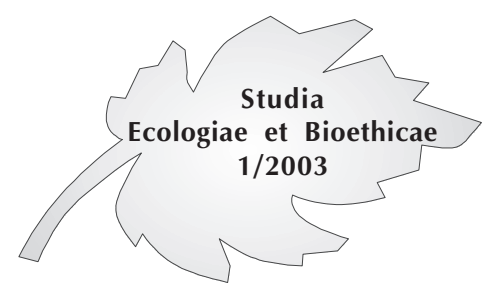

\title{
Międzynarodowa ochrona środowiska morskiego \\ - główne problemy, system regulacji oraz zasady i formy współpracy (zarys ogólny)
}

\section{Wprowadzenie}

1. Warto na wstępie przypomnieć, że morza i oceany zajmują ponad $71 \%$ powierzchni Ziemi. Ocean Światowy ma wpływ na około $90 \%$ jej życia biologicznego, a zmiany w ekosystemie wód morskich wywołują niekorzystne zjawiska i procesy na lądach. Główne zagrożenia dla Wszechoceanu to: zmiany fizyczne i chemiczne $\mathrm{w}$ jego środowisku, nadmierna eksploatacja jego zasobów, zanieczyszczenia z lądu, tankowce i testy nuklearne. Na stan środowiska morskiego wywiera wpływ wiele czynników, którymi zajmują się takie nauki jak geofizyka morska, biologia i chemia morska, klimatologia, ichtiologia, ekologia, czy oceanologia i oceanografia.

Geofizyka morska bada zagadnienie jaki wpływ na stan środowiska morskiego wywierają ruchy tektoniczne, ich struktura i skutki. Dzięki rozwojowi odpowiednich narzędzi badawczych, technologicznych oraz współpracy międzynarodowej $\mathrm{w}$ tym zakresie osiągane jest lepsze rozpoznanie i rozumienie procesów zachodzących w środowisku morskim naszej Planety ${ }^{1}$.

Badania geofizyczne wykazują współzależność w sensie fizycznym atmosfery i oceanu, także ich wpływu na obroty Ziemi, jako pewnej bazy dla jej wspólnej, ogólnej dynamiki². Istnieją bowiem dość ścisłe relacje między tymi dwoma środowiskami w sensie ich wzajemnego oddziaływania, co wiąże się także $\mathrm{z}$ zagadnieniem ochrony środowiska i przenoszenia zanieczyszczeń także pochodzenia antropogenicznego.

\footnotetext{
Instytut Studiów Międzynarodowych, Wydział Dziennikarstwa i Nauk Politycznych Uniwersytetu Warszawskiego.

1 E. J. W. Jones, Marine Geophisics, J. Willey, Chichester (UK) 1999; A. C. Duxbury, A. B. Duxbury, K.A. Sverdrup, Oceany świata, Wyd. PWN, Warszawa 2003.

2 N. Wells, The Atmosphere and Ocean. A Physical Introduction. 2nd Edition, J. Willey, Chichester (UK) 1997.
} 
Procesy dryfowania kry lodowej, cyrkulacje prądów oceanicznych mają wpływ na klimat i środowisko morskie ${ }^{3}$. Badanie tych zjawisk jest znaczące poznawczo i może być użyteczne przy interpretowaniu zjawisk ekologicznych.

Badania procesów chemicznych $\mathrm{w}$ środowisku morskim obejmują problemy równowagi $\mathrm{w}$ tym środowisku oraz oddziaływanie atmosfery powietrznej i wód oraz wód i występujących w nich osadów. Dotyczy to cykli procesów chemicznych z udziałem substancji organicznych i nieorganicznych, obecnie dokładniej, mierzalnie badanych, dzięki zastosowaniu zaawansowanych technologii analitycznych ${ }^{4}$. Podejmowane są badania biogeochemicznych procesów w Oceanie Światowym i ich rola w przemieszczaniu produktów służących żywieniu i „produkcji biologicznej" ${ }^{\prime \prime}$. Wyłania się bowiem paradygmat dla roli związków węgla występujących w tym Oceanie i ich znaczenia dla modelowania ekosystemu.

W systemie środowiska morskiego i jego ochrony są ostatnio bardziej postrzegane namorzyny (mangroves) jako swoiste ekosystemy flory $\mathrm{w}$ nadmorskich strefach subtropiku i tropiku (Ameryka, Azja, Australia, Wyspy Oceanu Spokojnego) ${ }^{6}$.

Badana jest dynamika modelowania zachowania środowiska morskiego $^{7}$. Różnorodność biologiczną, ekosystem, naruszają m.in. działania powodujące niszczenie glonów i zagładę populacji wielorybów. Zachowanie ekosystemu morza wymaga szczególnie bogatej wiedzy z różnych dziedzin w celu badania zagrożeń pochodzących z różnych źródeł i lepszego rozumienia ich istoty. Dynamiczne modelowanie ochrony środowiska wymaga rozpoznania metod jak dane systemy działają, określenia jak przyrodnicze i ludzkie działania prowadzą do zagrożenia tego środowiska oraz jaki może być najlepszy wpływ „świata morskiego" na zachowanie różnorodności biologicznej w morzach i oceanach. Modelowanie i prognozowanie środowiska stosowane jest m.in. przez oceanografię .

Troską społeczności międzynarodowej w przedsiębranych proekologicznych regulacjach prawnych, $\mathrm{w}$ tym powszechnych i regionalnych, jest

J. Bishof, Ice Drift, Ocean Circulation and Climate Change, Springer, Heidelberg 2000.

4 A. Gianguzza, E. Pelizzetti, S. Sammartano, Chemical Processes in Marine Environment, Springer, Heidelberg 2000 oraz tychże autorów: Chemistry of Marine Waters and Sediments, Springer, Heidelberg 2002.

5 M. J. R. Fasham, J. Gield, T. Platt, B. Zeitschel (eds.), Ocean Biogeochemistry. A. JGOFS Synthesis, Springer, Heidelberg 2002.

6 L. D. De Lacerda (ed.), Mangrove Ecosysytems. Function and Management. Springer, Heidelberg 2002.

7 M. Ruth (ed.), Dynamic Modelling for Marine Conservation, Springer, Heidelberg 2002.

8 G. Peng, L.M. Leslie, Y. Shao (eds.), Environmental Modelling and Prediction, Springer, Heidelberg 2002. 
Międzynarodowa ochrona środowiska morskiego - główne problemy...

problem rybołówstwa morskiego postrzegany konsekwentnie - na ogół w kontekście zachowania i ochrony środowiska naturalnego mórz i oceanów. Świadczy o tym m.in. „wspólna polityka rybołówstwa” UE, zwłaszcza w strefach przybrzeżnych państw nadmorskich ${ }^{9}$. Postulowana jest potrzeba zrewidowania uszczuplania praw, które ograniczają dostęp statków do stref nadbrzeżnych państw, a to w celu umożliwienia przywrócenia odpowiedniej równowagi. W zarządzaniu rybołówstwem uwzględniany jest także udział państw europejskich. Przyszłość zarządzania rybołówstwem przybrzeżnym wiąże się z niedocenianą rolą jaką spełnia $\mathrm{w}$ gospodarce lokalnej i regionalnej m.in. w europejskim kompleksie zarządzanie linią brzegową.

Usprawnieniu zarządzania rybołówstwem mogą służyć urządzenia elektroniczne, owa „rewolucja mikrokomputerów”, a także technologiczne innowacje i stosowanie nowych technologii do rozwiązywania $\mathrm{w}$ praktyce różnych problemów ${ }^{10}$. Nowe procedury służą określaniu miejsc krytycznych usytuowania zasobów biologicznych w morzach, monitorowania ich zachowania się i procesów ich fizjologii oraz syntetyzowania wyników badań $\mathrm{w}$ formie modeli różnych populacji ryb. Te pierwsze syntezy metod badawczych dysponujących środkami elektronicznymi do badań rybołówstwa morskiego mogą stać się standardami na tym polu działań do planowania badań z użyciem tych środków w przyszłości.

2. Z definiowaniem zanieczyszczeń środowiska, w tym także morskiego, wiążą się koncepcje jego wykorzystania przez człowieka tj. idea melioracji, dopuszczająca jego modyfikowanie; idea konserwacji - dopuszczająca tylko te działania, które nie naruszają stanu równowagi środowiska; oraz idea kontroli wykorzystania środowiska dla potrzeb ludzkich, zobowiązująca do podejmowania działań, które by je chroniło przed utratą zdolności do samooczyszczania.

$\mathrm{Z}$ koncepcji tych wynikały pewne modelowe definicje zanieczyszczenia, które jednak dotyczyły tylko skutków działań człowieka, a pomijały zanieczyszczenia powstałe $\mathrm{w}$ wyniku działania sił przyrody. Uwzględniając wzrost świadomości ekologicznej oraz wymogi związane z rozwojem gospodarczym, w podejmowanych próbach definiowania zjawiska zanieczyszczenia środowiska, skłaniano się do koncepcji kontroli wykorzystania środowiska.

9 David Symes, Jeremy Philipson (eds.), Inshore Fisheries Management, Kluwer, Dordrecht 2001.

10 Electronic Tagging and Tracking in Marine Fisheries, edited by John R. Sibert, Jenniger L. Nielsen, Kluwer, Dordrecht, 2001. Użyteczny może być także: Dictionary of Environmental Science and Technology, 3rd Edition, autor A. Porteous z The Open University, wyd. J.W. JWilley, Chichester (UK), 2000. Zawiera nowe hasła dot. różnorodności biologicznej, biotechnologii, teledetekcji satelitarnej i organizmów genetycznie zmodyfikowanych a także Szczytu Ziemi w Rio i Agendy 21. 
Przyjęta w Konwencji NZ o prawie morza (1982) definicja zanieczyszczenia morza jest wzorowana na definicji przyjętej przez Wspólną Grupę Ekspertów ds. Naukowych Aspektów Zanieczyszczeń Morskich (GESAMP) utworzoną przez Podkomitet ds. Zanieczyszczeń Morskich Międzynarodowej Organizacji Morskiej (IMO). Ta zaś definicja została wcześniej po raz pierwszy zaproponowana przez Komitet Naukowy Badań Oceanicznych działający w strukturach Międzynarodowej Rady Organizacji Naukowych, a następnie przyjęta przez GESAMP. Nawiązano do jej treści na konferencji NZ w Sztokholmie (1972), co znalazło wyraz w art. 7 przyjętej wówczas Deklaracji ${ }^{11}$.

Konwencja o prawie morza w art. 1 ust. 1, pkt. 4 podaje następującą definicję: „zanieczyszczanie środowiska morskiego oznacza takie bezpośrednie lub pośrednie wprowadzanie przez człowieka substancji lub energii do środowiska morskiego, łącznie z estuariami, które powoduje lub może powodować takie szkodliwe następstwa jak: szkody wyrządzone żywym zasobom i życiu w morzu, niebezpieczeństwa dla zdrowia człowieka, przeszkody $\mathrm{w}$ działalności na morzu, $\mathrm{w}$ tym $\mathrm{w}$ poławianiu i w innych zgodnych z prawem sposobach korzystania z morza, obniżanie jakości użytkowej wody morskiej i pogarszanie warunków wypoczynku".

Do głównych zagrożeń dla środowiska morskiego należą zanieczyszczenia spowodowane "zatapianiem", żeglugą i eksploatacją podmorskich zasobów ropy naftowej. Pod pojęciem „zatapianie” Konwencja o prawie morza (art. 1, ust. 1 pkt. 5 a i b) rozumie: „(i) każde umyślne usuwanie odpadów i innych materiałów ze statków morskich, statków powietrznych, platform lub innych konstrukcji zbudowanych na morzu; (ii) każde umyślne niszczenie statków morskich, statków powietrznych, platform lub innych konstrukcji zbudowanych na morzu".

Żegluga morska stwarza zagrożenia jakie występują w wyniku awarii, której przyczyną mogą być trudne warunki żeglugowe, stan eksploatowanego sprzętu oraz błędy ludzi, operatorów. Najbardziej niebezpieczne dla środowiska morskiego są katastrofy tankowców, powodujące rozlewy tysięcy ton ropy, m.in. te z udziałem "Torrey Canynon" (1967), "Globe Asimi” (1981), „Exxon Valdex” (1989), „Prestige” (2002), czy innych tankowców. Zanieczyszczenia mórz powstają także w czasie normalnej eksploatacji statków, a to w wyniku: przedostawania się do wód pewnych ilości substancji ropopochodnych, awaryjnych zrzutów przewożonych ładunków, operacji przeładunkowych, mycia zbiorników przeładunkowych statków wodą zaburtową, wodą z dodatkiem detergentów, czy wodą ciepłą.

11 M. TomczaK, Defining Marine Pollution. A Comparison of Definitions Used by International Conventions, Marine Policy, October 1984, s. 312; P. Lewandowski, Prawna ochrona wód morskich i śródlądowych przed zanieczyszczeniami. Gdańsk 1996, s. 13, 16. 
Międzynarodowa ochrona środowiska morskiego - główne problemy...

Konwencja MARPOL wprowadziła odpowiednio rygorystyczne normy czystości dotyczące zrzutu tzw. popłuczyn za burtę statku.

Duże zagrożenia w postaci wycieków i zanieczyszczeń spowodowanych przeładunkiem, czy w wyniku awarii szybów wiertniczych, bądź zaniedbań stwarza eksploatacja podmorskich zasobów ropy naftowej. Na skutek niekontrolowanej erupcji ropy i gazu, powstałych w wyniku błędu operatorów lub nieprzewidzianego wzrostu ciśnienia w danym złożu, może zaistnieć taka sytuacja jak na polu naftowym „Ixtoc 1" w Zatoce Meksykańskiej, gdzie wyciek ropy trwał 295 dni, powodując przedostanie się do wód morskich 600 tys. ton ropy. Rozlewy ropy mogą być także powodowane ruchami tektonicznymi skorupy ziemskiej, bądź też przez jej przesączanie się przez podłoże.

Zanieczyszczenia ropopochodne ${ }^{12}$ oddziaływują bezpośrednio na środowisko już w trakcie rozlewu i powodują długotrwałe skutki. Ograniczają wymianę gazów między atmosferą i wodą, uniemożliwiając jej dotlenianie, zmniejszają dopływ światła do fitoplanktonu utrudniając fotosyntezę. Powodują hamowanie procesów biologicznych i obumieranie organizmów żywych w środowisku morskim. Wchłaniane przez nie węglowodory powodują choroby, degenerację, bądź wyginięcie gatunków szczególnie wrażliwych. Opadając tworzą nieprzenikalną warstwę na dnie morza, naruszającą równowagę biologiczną i powodującą zamieranie występującego tam życia. Ropa oblepiając ryby, foki, czy ptaki morskie powoduje ich okaleczenie lub śmierć, degraduje też faunę i florę na brzegu morza.

Wysoce szkodliwe dla środowiska morskiego są też zanieczyszczenia pochodzące $\mathrm{z}$ lądu, w postaci ścieków przemysłowych, komunalnych i „rolniczych spływów powierzchniowych”, zawierających różne substancje z nawozów sztucznych, powodujące m.in. zmiany w modelu wzrostu glonów morskich.

\section{System regulacji}

1. Kształtowanie się systemu regulacji międzynarodowych służących ochronie środowiska morskiego to pewien długotrwały proces ${ }^{13}$, zapo-

12 Zob. T. GRACZYK, Ochrona środowiska morskiego przed zanieczyszczeniami ropopochodnymi, Szczecin, Wyd. Uczelniane PS, 1996.

13 Zob. Valentina Germani, Marine environment from the conclusion of the United Nations Convention on the Law of the Sea to the World Summit on Sustainable Development, New York 2002; L. Łukaszuk, Międzynarodowe prawo morza, Scholar, Warszawa 1997, s. 181196. Zob. także J. Ciechanowicz, Międzynarodowe prawo ochrony środowiska, Warszawa, Wyd. Prawnicze PWN, 1999; J. CIEChanowicz, Ochrona środowiska: zbiór przepisów, Gdańsk: Lex, 1994; G. Grabowska, Europejskie prawo środowiska, Warszawa: Wydawnictwa Prawnicze PWN, 2001. M.A. NesTEROwICZ, Ochrona prawna Battyku przed zanieczyszczeniem, Państwo i Prawo, 2000 r. nr 8, s. 79-88. 
czątkowany przyjęciem przez Narody Zjednoczone Deklaracji Sztokholmskiej (1972), w której trzy zasady $(7,21$ i 22) dotyczyły bezpośrednio problematyki morskiej, a zalecenia (87-94) - wzywały państwa do zwiększenia kontroli stanu środowiska $\mathrm{w}$ morzach i oceanach. Zasady odnosiły się do: zapobiegania zanieczyszczeniom mórz przez substancje, które mogą stanowić zagrożenie dla zdrowia ludzkiego, niszczyć zasoby naturalne mórz, oraz uniemożliwiać legalne korzystanie z tych zasobów; odpowiedzialności państw za spowodowanie zanieczyszczeń transgranicznych; zachęcano też państwa do rozwijania norm międzynarodowych dotyczących odpowiedzialności i kompensowania szkód spowodowanych w środowisku naturalnym.

Deklaracja wpłynęła na zwiększenie zainteresowania środowiskiem morskim i jego ochroną, czego wyrazem było m.in. przyjęcie w 1972 r. Konwencji o ochronie fok arktycznych oraz Konwencji o zapobieganiu zanieczyszczania mórz przez zatapianie $\mathrm{w}$ nich odpadów radioaktywnych. Uregulowania te nie miały jednak szerszego znaczenia, bowiem objęły tylko część ekosystemu morskiego. Rozwinęły się natomiast porozumienia regionalne, bardzo znaczące dla ochrony środowiska morskiego ze względu na potencjalnie większą ich efektywność.

W Europie podpisano w 1974 i 1976 trzy ważne konwencje: Paryską (1974) o zapobieganiu zanieczyszczeniom z lądu Atlantyku północnowschodniego i Morza Północnego; Helsińską $(1974,1992)$ o ochronie środowiska Morza Bałtyckiego i Konwencję (1976) o ochronie Morza Śródziemnego.

Międzynarodowe regulacje prawne odnoszące się do środowiska morskiego są stosunkowo nową częścią prawa morza i należą także do prawa ekologicznego (ochrony środowiska), które w znacznej mierze ma też międzynarodowy zasięg, bowiem dotyczy zdarzeń i ich skutków transgranicznych. Najbardziej znaczącym zbiorem uregulowań obejmujących ochronę środowiska morskiego są te należące do prawa publicznego i są one zawarte w konwencjach powszechnych i regionalnych. Regulacje te ukształtowały wiele zasad i form współpracy międzynarodowej. Ochrona środowiska morskiego jest przedmiotem wielu regulacji należących do prawa międzynarodowego i prawa krajowego ${ }^{14}$. Do regulacji po-

14 Konwencje międzynarodowe powszechne to głównie:

- Konwencja o prawie morza z 1982 r., a głównie jej część XII poświęcona ochronie i zachowaniu środowiska morskiego; teksty w j. polskim i angielskim w DzU RP, zał. do nru 59 poz. 543 z 20.05.2002 r.;

- Międzynarodowa konwencja o zapobieganiu zanieczyszczeniu morza przez statki - MARPOL;

· Międzynarodowa konwencja o bezpieczeństwie życia na morzu SOLAS, wraz z późniejszymi zmianami. 
wszechnych międzynarodowych, oprócz Konwencji o prawie morza (1982) należą głównie konwencje Międzynarodowej Organizacji Morskiej (IMO), są też konwencje o zasięgu regionalnym, niekiedy odnoszące się do jednego akwenu oraz regulacje towarzystw klasyfikacyjnych.

Konwencje o zasięgu regionalnym - to m.in.:

- Międzynarodowa konwencja o zanieczyszczeniu olejami, podpisana w Londynie w 1954 r.;

- Międzynarodowa konwencja o interwencji na Morzu Północnym w przypadku spowodowania zanieczyszczeń olejami, podpisana w Brukseli 1969 r.;

- Międzynarodowa konwencja o odpowiedzialności cywilnej z tytułu szkód wyrządzonych przez zanieczyszczenia olejowe, podpisana w Brukseli 1969 r.;

- Porozumienie w sprawie współpracy przy zwalczaniu zanieczyszczeń olejowych Morza Północnego, podpisane w Bonn 1969 r.;

- Porozumienie nordyckie o współpracy w podejmowaniu wysiłków zapobiegających zanieczyszczeniom morza przez oleje, podpisane w Kopenhadze 1971 r. przez Danię, Finlandię, Norwegię i Szwecję;

- Konwencja o zapobieganiu zanieczyszczaniu mórz przez zatapianie odpadów i innych substancji z 1972 r.;

- Protokół dotyczący interwencji na Morzu Północnym w przypadku zanieczyszczenia morza substancjami innymi niż oleje, podpisany w Londynie $1973 \mathrm{r}$.

- Konwencja o ochronie środowiska morskiego obszaru Morza Bałtyckiego podpisana w Helsinkach 1974 r.;

- Protokół o współpracy w zwalczaniu zanieczyszczeń Morza Śródziemnego przez oleje i inne szkodliwe substancje, podpisana w Barcelonie1976 r.;

- Konwencja o ochronie żywych zasobów morskich Antarktyki, podpisana w Canberze $1980 \mathrm{r}$.

- Protokół o ochronie środowiska do Układu w sprawie Antarktyki, sporządzony w Madrycie, z 4 października $1991 \mathrm{r}$;

- Konwencja helsińska o ochronie środowiska morskiego obszaru Morza Bałtyckiego z dnia

9 kwietnia $1992 \mathrm{r}$.

Prawo wewnętrzne RP obejmuje następujące akty:

- Ustawa o zapobieganiu zanieczyszczeniu morza przez statki z 16 marca 1995 r.;

- Rozporządzenie Ministra Transportu i Gospodarki Morskiej z 20 grudnia 1996 r. jako akt wykonawczy do Ustawy o zapobieganiu zanieczyszczeniu morza przez statki w sprawie przepisów technicznych w zakresie zapobiegania zanieczyszczeniu morza przez statki, trybu prowadzenia przeglądów i inspekcji, wzorów międzynarodowych świadectw, wysokości opłat w tym związanych oraz powierzenie niektórych zadań organu inspekcyjnego instytucji klasyfikacyjnej;

- Rozporządzenie Ministra Transportu i Gospodarki Morskiej z 6 stycznia 1998 r. do Ustawy o zapobieganiu zanieczyszczeniu morza przez statki w sprawie trybu wydawania zezwoleń na usuwanie do morza urobku z pogłębiania dna oraz na zatapianie w morzu odpadów lub innych substancji;

· Rozporządzenie Rady Ministrów z 3 grudnia 2002 r. do Ustawy o zapobieganiu zanieczyszczaniu morza przez statki, w sprawie organizacji i sposobu zwalczania zagrożeń i zanieczyszczeń na morzu;

- Ustawa o bezpieczeństwie morskim, z 9 listopada 2000 r.;

- Rozporządzenie Ministra Infrastruktury z 20 listopada 2000 r. do Ustawy o bezpieczeństwie morskim w sprawie określenia trybu uznawania instytucji klasyfikacyjnej do sprawowania nadzoru technicznego nad statkami oraz rodzajów i zakresów przeglądu statków morskich; 
2. Konwencja NZ o prawie morza (1982) tworzy ogólne, ale dość szeroko ujęte ramy prawne dla celów powszechnej ochrony środowiska morskiego oraz mechanizmy mające ułatwiać korzystanie z Oceanu Światowego przez różne podmioty prawa międzynarodowego, przy uwzględnieniu wielu różnych interesów, z pewną preferencją dla krajów rozwijających się. Kształtuje system propagujący zrównoważony rozwój, służyć może wspomaganiu rozwojowi i transferowi osiągnięć nauki i technologii morskich. Może być także postrzegana jako pewien model sprzyjający dalszemu kształtowaniu prawa ochrony środowiska morskiego. Określono w niej pojęcie i główne źródła zanieczyszczeń tego środowiska, a także obowiązki państw i organizacji międzynarodowych w zakresie jego ochrony i zachowania. Konwencja stanowi też o zasadach odpowiedzialności za szkody wyrządzone środowisku morskiemu oraz o regulowaniu sporów. Określono też relacje tej Konwencji z innymi regulacjami międzynarodowymi. Tak więc stanowi ona istotny element międzynarodowego systemu ochrony środowiska morskiego.

W Konwencji o prawie morza zobowiązano państwa do podejmowania wszelkich środków koniecznych do zapobiegania zanieczyszczeniom środowiska morskiego z jakichkolwiek źródeł, ich zmniejszania i kontroli (art. 194). Dotyczy to: wprowadzania toksycznych, niebezpiecznych i szkodliwych substancji, szczególnie trwałych, pochodzących ze źródeł lądowych, przenoszonych przez atmosferę lub na skutek zatapiania; zanieczyszczeń ze statków powstałych w wyniku wypadków, a także umyślnych i zamierzonych zrzutów; zanieczyszczeń pochodzących z instalacji i urządzeń używanych do badania lub eksploatacji zasobów naturalnych dna morskiego lub jego podziemia; zanieczyszczania środowiska morskiego z innych instalacji i urządzeń eksploatowanych w środowisku morskim.

Państwa mają obowiązek powiadamiać zagrożone kraje o grożących środowisku morskiemu niebezpieczeństwach, odpowiednio planować

- Ustawa kodeks morski, z 18 września 2001 r.;

- Ustawa prawo wodne, z 18 listopada 2001 r.;

- Ustawa o portowych urządzeniach do odbioru odpadów oraz pozostałości ładunkowych ze statku, z 12 września 2002 r.

Ochronę środowiska morskiego w Polsce regulują umowy międzynarodowe i prawo wewnętrzne. Polska ratyfikowała wiele umów dotyczących ochrony wód morskich oraz dostosowała prawo wewnętrzne do postanowień umów międzynarodowych. Są to m.in.:

- Konwencja o ochronie fok antarktycznych, sporządzona w Londynie 1 czerwca 1972 r.;

- Konwencja o zapobieganiu zanieczyszczeniu mórz przez zatapiane odpadów i innych substancji, sporządzona w Moskwie, Waszyngtonie, Londynie i Meksyku, 29 grudnia 1972 r.; - Międzynarodowa konwencja o zapobieganiu zanieczyszczeniu morza przez statki, sporządzona w Londynie, 2 listopada 1973 r.;

- Konwencja Narodów Zjednoczonych o prawie morza, przyjęta w Montego Bay, 10 grudnia $1982 \mathrm{r}$. 
Międzynarodowa ochrona środowiska morskiego - główne problemy...

działania na wypadek zagrożeń, prowadzić badania oraz wymieniać informacje i dane w celu stosowania naukowych kryteriów przy opracowywaniu zasad, standardów i procedur oraz podejmowaniu działań praktycznych.

Państwa powinny jednak unikać nieuzasadnionego interweniowania w działania podejmowane przez inne państwa, wykonujące swe prawa przewidziane w Konwencji.

Konwencja o prawie morza szczegółowo reguluje wiele kwestii, których nie uwzględniają tzw. konwencje ekologiczne ${ }^{15}$. Dotyczy to m.in. zapewnienia przez państwo bandery, aby jego statki odpowiadały standardom międzynarodowym w zakresie ochrony środowiska morskiego, z zakazem używania statków substandardowych i obowiązku prowadzenia dochodzeń w wypadku zanieczyszczenia morza oraz kontrolowania obcych statków, a także ich zatrzymania przy zaistnieniu obiektywnych powodów ${ }^{16}$.

W Konwencji wyeksponowano problematykę zanieczyszczeń pochodzących ze źródeł lądowych (art. 207), określając odpowiednio:

- najważniejsze rodzaje źródeł takich zanieczyszczeń w postaci: rzek, estuariów, rurociągów i konstrukcji wylotów kanałów ściekowych;

- wymóg, aby państwa poprzez właściwe organizacje międzynarodowe lub konferencje dyplomatyczne dążyły do ustanowienia powszechnych i regionalnych zasad, standardów praktyk i procedur $\mathrm{w}$ celu zmniejszania i kontroli zanieczyszczeń środowiska pochodzących z lądu, biorąc pod uwagę charakterystyczne cechy regionalne, potencjał ekonomiczny państw rozwijających się oraz ich potrzeby rozwoju gospodarczego;

- obowiązek państw do wydania stosownych ustaw i innych przepisów dotyczących zapobiegania, zmniejszania i kontroli zanieczyszczeń środowiska morskiego pochodzących ze źródeł lądowych; zobowiązano je do uwzględniania w tych regulacjach ustalonych międzynarodowych zasad, i standardów oraz zalecanych praktyk i procedur;

- obowiązek państw do podjęcia także innych środków koniecznych do zapobiegania, zmniejszania takich zanieczyszczeń i ich kontroli;

- wymóg, aby wszystkie te regulacje oraz procedury obejmowały działania mające na celu zmniejszenie w najszerszym zakresie zrzutów do środowiska morskiego substancji toksycznych, szkodliwych lub niebezpiecznych, trwale oddziałujących na środowisko morskie;

- obowiązek państw do koordynowania swoich działań $w$ zakresie ochrony środowiska morskiego przed zanieczyszczeniem $\mathrm{z}$ lądu w relacjach regionalnych.

15 M.H. Koziński, Morskie prawo publiczne, Wyższa Szkoła Morska w Gdyni, Gdynia 1997, s. 149.

16 R. Hyra, Wtadcze uprawnienia państw a ochrona środowiska w prawie morza (Zagadnienia wybrane), Państwo i Prawo, 1994, nr 6, s. 64-65. 
Ochrona morza przed zanieczyszczeniami z lądu wymaga odpowiedniego skorelowania i zsynchronizowania $\mathrm{z}$ umowami międzynarodowymi aktów prawa wewnętrznego zwłaszcza tych państw, na których obszarze znajdują się źródła zagrożenia środowiska morskiego.

Z przepisów XII rozdziału Konwencji o Prawie morza wynikają cztery główne zasady, będące podstawą ochrony i zachowania środowiska morskiego.

1) Zasada ochrony środowiska morskiego, usytuowana w art. 192 jako ius cogens: „Państwa są zobowiązane do ochrony i zachowania środowiska morskiego". Tak więc obowiązek ochrony środowiska oraz polityka ochrony środowiska, wiążą państwo w korzystaniu z jego uprawnień do eksploatacji zasobów naturalnych.

2) Zasada współpracy międzynarodowej państw na forum właściwych organizacji międzynarodowych $\mathrm{w}$ celu formułowania i opracowywania międzynarodowych regut, standardów oraz zalecanych praktyk i procedur - zgodnie z Konwencją o prawie morza (art. 194 oraz art. 207 ust. 4, podkreślający rangę współpracy regionalnej).

Wprowadzono obowiązek notyfikacji o grożącej lub faktycznej szkodzie powstałej na skutek zanieczyszczenia środowiska (art. 198). Przewidziano też stworzenie systemu informacji o jakości i zagrożeniu środowiska, ustalenie ogólnie obowiązujących norm określających maksymalny dopuszczalny poziom zanieczyszczenia mórz, a także rozwijanie wielostronnej współpracy naukowo-technicznej i dążenie do zwiększania skuteczności technicznej środków zwalczania zanieczyszczeń.

3) Zasada samoobrony - to prawo państw do podjęcia wszelkich środków, koniecznych dla zapobiegania, zmniejszania i kontroli zanieczyszczeń środowiska morskiego, co dotyczy zanieczyszczeń ze źródeł lądowych (art. 207), zanieczyszczeń powstałych na skutek działalności na dnie morza (art. 208), zanieczyszczeń powstających w wyniku eksploatacji wyłącznej strefy ekonomicznej (art. 209), zanieczyszczeń przez zatapianie (art. 210), zanieczyszczeń ze statków (art. 211), zanieczyszczeń z powietrza (art. 212). Inne odpowiednie przepisy tej Konwencji dotyczą zapewnienia wykonania tej zasady.

Stosowanie w praktyce zasady samoobrony wyraża się m.in. w uprawnieniach państw portu pozwalających na odpowiednie działania kontrolne wobec obcego statku w celu sprawdzenia jego dokumentów, czy potwierdzają one przestrzeganie międzynarodowych przepisów i standardów dotyczących zapobiegania zanieczyszczeniom morza oraz $\mathrm{w}$ celu zbadania ich zgodności ze stanem faktycznym. Państwo nadbrzeżne może także przeprowadzać inspekcje na statkach będących $w$ tranzycie na wodach terytorialnych.

4) Zasada odpowiedzialności państw za zanieczyszczenia środowiska morskiego została ujęta ogólnie, bez określenia jej szczegółowych za- 
Międzynarodowa ochrona środowiska morskiego - główne problemy...

sad. Państwa są odpowiedzialne za wykonanie swoich zobowiązań międzynarodowych dotyczących ochrony i zachowania środowiska morskiego. Przewidziano odpowiedzialność państw w związku ze szkodą powstałą w środowisku morskim, która nastąpiła w trakcie korzystania $\mathrm{z}$ prawa nieszkodliwego przepływu, niezakłóconego tranzytu lub przejścia szlakiem archipelagowym.

Wiele uwagi poświęcono w Konwencji odpowiedzialności karnej za zanieczyszczanie morza. Przewiduje się możliwości nakładania kar pieniężnych, które państwa nadbrzeżne mogą wymierzać za naruszenie prawa wewnętrznego obowiązującego $\mathrm{w}$ danej strefie lub przepisów i standardów międzynarodowych przez obce statki poza granicami morza terytorialnego (art. 230).

Odpowiedzialność państw za zanieczyszczenie środowiska morskiego oparto na przesłankach obiektywnych. Postanawia się bowiem m.in., że w zakresie ubezpieczenia i odpowiedniej kompensacji za szkodę spowodowaną przez zanieczyszczenie środowiska morskiego państwa mają współpracować w celu wprowadzenia w życie obowiązujących norm prawa międzynarodowego (art. 235, ust. 2).

Istotne w nowym prawie morza jest szerokie określenie obowiązków i odpowiedzialności państw, dla których podstawowym zobowiązaniem jest, "ochrona i zachowanie środowiska naturalnego", (art. 192). Zostało to odpowiednio skorelowane $\mathrm{w}$ art. $193 \mathrm{tj}$. $\mathrm{z}$ ich suwerennymi prawami do korzystania z zasobów naturalnych. Służy to zespalaniu gospodarczych interesów narodowych państw z ich obowiązkiem respektowania interesów ogólnych $\mathrm{w}$ zakresie ochrony i zachowania środowiska naturalnego. Drogą normy międzynarodowego prawa zwyczajowego, rozszerzono więc odpowiedzialność państw za stan oceanów.

Konwencja nakłada też na państwa obowiązek podejmowania odpowiednich środków w celu zwalczania zanieczyszczeń powstałych na skutek stosowania technologii lub wprowadzania do mórz nowych lub obcych gatunków zagrażających życiu biologicznemu mórz.

Państwa maja obowiązek niedopuszczania do przemieszczania szkody lub zagrożeń $\mathrm{z}$ jednego miejsca $\mathrm{w}$ drugie, bądź przekształcanie się jednego typu zanieczyszczenia w inny (art. 195).

Państwa i organizacje międzynarodowe zobowiązano do udzielania specjalistycznej pomocy naukowej i technicznej państwom rozwijającym się w celu zwalczania zanieczyszczeń środowiska morskiego (art. 202-203).

W Konwencji państwa zobowiązały się do tworzenia i dążenia do tworzenia zasad i norm - powszechnych bądź regionalnych standardów i rekomendacji praktycznych, mających na celu zapobieganie, redukowanie i kontrolę zanieczyszczeń pochodzących z różnych źródeł. Mogą one działać poprzez organizacje międzynarodowe bądź konferencje dyplomatyczne. 
Państwa zobowiązano do obowiązkowego wprowadzenia norm międzynarodowych dotyczących ochrony środowiska morskiego, do prawa wewnętrznego. W Konwencji określono też relacje między normami i standardami międzynarodowymi a uregulowaniami krajowymi biorąc pod uwagę różne rodzaje zanieczyszczeń. Ma to umożliwić odpowiednie ujednolicenie ustawodawstwa, a przez to zwiększenie bezpieczeństwa ekologicznego $\mathrm{w}$ użytkowaniu oceanów, podobnie jak to zastosowano $\mathrm{w}$ przypadku żeglugi morskiej.

W konwencji przewiduje się też przymusowe procedury rozstrzygania sporów, a także obowiązkowe ubezpieczenia.

Można tu zauważyć, że Konwencja o prawie morza z 1982 r. odnosi się do wszystkich obszarów morskich i wprowadza w skali globalnej obowiązki państw do ochrony i zachowania środowiska wobec grożących mu zanieczyszczeń z różnych źródeł. Przepisy Konwencji posłużyły do przyjęcia wielu konwencji powszechnych, regionalnych i bilateralnych, służących ochronie środowiska morskiego.

Do ochrony środowiska morskiego mają także zastosowanie inne konwencje o powszechnym zasięgu obowiązywania, a także regulacje regionalne. Jest wśród nich Konwencja Bałtycka (Helsińska z 1992 r.).

3. Konwencja Helsińska z 1992 r., którą podpisało 9 państw nadbałtyckich oraz Wspólnoty Europejskiej wprowadza rozwiązania uproszczone i bardziej precyzyjne niż Konwencja z 1974 r., uwzględniając kompleksowo kwestie związane $\mathrm{z}$ ochroną środowiska $\mathrm{w}$ regionie bałtyckim. Przewiduje ona ochronę Bałtyku przed zanieczyszczeniem wszelkimi szkodliwymi substancjami pochodzącymi ze wszystkich źródeł przed niekorzystnym oddziaływaniem za pomocą energii, na przykład przez promieniowanie czy wywoływanie zmian temperatury, a ponadto uwzględnia ochronę przed innymi czynnikami i działaniami stwarzającymi zagrożenie dla środowiska morskiego, takimi jak spalanie i bagrowanie.

Pojęcie zanieczyszczenia z lądu w Konwencji z 1992 r. jest bardziej rozwinięte i wprowadza klasyfikację jego źródeł. Zanieczyszczenie to może być wprowadzone drogą wodną, powietrzną lub bezpośrednio $\mathrm{z}$ brzegu przez źródła lądowe punktowe i rozproszone. Obejmuje także zanieczyszczenia powodowane deponowaniem pod dnem morskim, tunelem, rurociągiem lub inną drogą dostępną z lądu.

Zgodnie z Konwencją statki wykorzystywane do przewozów międzynarodowych na Bałtyku będą poddawane systematycznym kontrolom w celu ustalenia czy przestrzegane są jej postanowienia. Państwa bałtyckie dążą do zminimalizowania skażenia środowiska Bałtyku powodowane także przez statki turystyczne oraz $\mathrm{w}$ wyniku działalności rekreacyjnej.

Konwencja wprowadza zakaz spalania odpadów na statkach podczas ich pobytu na obszarze Bałtyku. 
Międzynarodowa ochrona środowiska morskiego - główne problemy...

W konwencji zakazano zatapiania w Morzu Bałtyckim jakichkolwiek odpadów lub innych substancji. Wyjątek stanowić mają jedynie sytuacje związane z ratowaniem życia ludzkiego, a także statku lub samolotu. Wypadki tego rodzaju wymagają notyfikacji Komisji Helsińskiej - HELCOM i mają być poddawane ścisłej kontroli państw według ustalonych zasad.

$\mathrm{W}$ konwencji zobowiązano państwa nadbałtyckie do podejmowania wszelkich właściwych środków w celu zapobieżenia zanieczyszczeniom środowiska morskiego Morza Bałtyckiego, powstałym w wyniku prowadzenia badań lub eksploatacji tej części dna morskiego i podłoża bądź jakiejkolwiek związanej z tym działalności oraz do zapewnienia odpowiedniego stanu gotowości do natychmiastowych akcji interwencyjnych $\mathrm{w}$ wypadku zaistnienia aktów zanieczyszczeń wywołanych takimi działaniami (art. 12).

Wprowadzono nowe obowiązki państw odnośnie zapobiegania zanieczyszczeniom wynikającym z działalności przybrzeżnej - zawiera je załącznik VI Konwencji. Są to postanowienia, których brak w Konwencji z 1974 roku.

Obecny system regulacji prawno-traktatowych odnoszących się do regionu Bałtyku jest zgodny z rozwojem nowego prawa morza, o czym świadczy chociażby przyjęcie podobnych definicji zanieczyszczenia i środków ochrony przed nim.

Podejmując rewizję Konwencji z 1974 r. zmierzano do zaostrzenia reżimu prawnego związanego z zapobieganiem i eliminacją następstw wynikających z działalności gospodarczej państw, skutkującej pogarszaniem się stanu środowiska Bałtyku. W związku z tym rozszerzono obszar działania Konwencji na morskie wody wewnętrzne. W Konwencji z 1992 r. zawarto nową koncepcję ochrony środowiska morskiego, przewidującą podejmowanie kompleksowych działań w całym zlewisku Morza Bałtyckiego. Dotyczy to zwłaszcza:

- podejmowania środków zaradczych przed określonymi substancjami mogącymi zanieczyszczać morze;

- wykorzystania Najlepszej Dostępnej Technologii (NDT), tzw. BAT Best Available Technology i Najlepszej Praktyki Ekologicznej (NBP), tzw. BEP - Best Environmental Practice w celu eliminowania zanieczyszczeń pochodzących z tzw. źródeł punktowych i rozproszonych;

- przyjęcia zasady, że za zanieczyszczenia płaci zanieczyszczający (tzw. PPP - Pulluter Pays Principle);

- przeprowadzania Ocen Oddziaływania na Środowisko planowanej działalności mogącej wywierać ujemny wpływ na środowisko.

Konwencja nakłada na państwa obowiązek prowadzenia kontroli emisji oraz zanieczyszczeń wody i powietrza. Wprowadza nowy przepis gwarantujący społeczeństwu szeroki dostęp do informacji o wynikach badań kontrolnych i sprawdzających zgodność z normami jakości wody, 
warunkach wydawania zezwoleń na wprowadzanie zanieczyszczeń oraz przewiduje zakaz spalania odpadów. Wprowadzono obowiązek ochrony walorów przyrodniczych ekosystemów morskich i przybrzeżnych, jak też zachowania różnorodności gatunków je zasiedlających.

W Konwencji tej rozszerzono pojęcie zanieczyszczeń z lądu, obejmując zanieczyszczenia ze źródeł punktowych i rozproszonych. Jednak o obowiązkach państw w zapobieganiu tym zanieczyszczeniom wypowiedziano się bardzo ogólnie.

Wybór środków prawnych i innych należy do wyłącznej kompetencji państwa. W dyrektywach Wspólnoty Europejskiej, skonkretyzowano te obowiązki w odniesieniu do państw należących do Unii Europejskiej.

Ważną rolę w implementacji Konwencji Helsińskiej odgrywają zalecenia, których treścią są najczęściej normy techniczne, zaliczane do tzw. „miękkiego prawa międzynarodowego". Zarówno przepisy Konwencji Helsińskiej, jak i zalecenia wydawane przez HELCOM są adresowane do państw, a nie do podmiotów indywidualnych na terenie tych państw. Stąd też przestrzeganie tych norm skutkuje wyłącznie odpowiedzialnością państw na płaszczyźnie prawnomiędzynarodowej.

Państwa przyjęły na siebie obowiązek niezanieczyszczania Bałtyku substancjami niebezpiecznymi, wymienionymi w aneksie do tej Konwencji. Owa „czarna lista” zawiera substancje szczególnie niebezpieczne (DDT, DDE i DDD oraz PCB). Szczegółowe regulacje dotyczące zapobiegania zanieczyszczeniom morza z lądu (art. 6 ust. 2) przewidują kontrolę i ograniczenie zanieczyszczeń przez szkodliwe dla zdrowia substancje i materiały wymienione $\mathrm{w}$ Aneksie II. Wymieniono tam takie substancje jak rtęć, kadm i antymon, które nie mogą być wprowadzane do środowiska bez uprzedniego zezwolenia władzy państwowej. (Treść Aneksu I jest zbieżna z decyzją Rady 75/4371/EWG oraz Dyrektywą Rady 76/ 4641/EWG.)

W załączniku III określono cele, kryteria i środki dotyczące zapobiegania zanieczyszczeniom z lądu, wyróżniając jako szczególnie niebezpieczne ścieki komunalne i przemysłowe. Komisja Helsińska (HELCOM), jako organ wykonawczy Konwencji przyjęła wiele zaleceń dotyczących zwalczania zanieczyszczeń ze źródeł lądowych ${ }^{17}$.

17 Są to m.in.: Zalecenie 7/4 dotyczące podjęcia działań w celu zredukowania zrzutów ścieków z obszarów zabudowanych poprzez wstępne oczyszczanie ścieków pochodzących z zakładów przemysłowych; Zalecenie 9/8 dotyczy środków służących redukcji zanieczyszczeń pochodzących z przemysłu; Zalecenie 12/4 dotyczące zasad odprowadzania ścieków przemysłowych do systemów kanalizacji miejskiej; Zalecenie 11/3 dotyczące ograniczenia zrzutów z zakładów przemysłu produkującego siarczynową masę celulozową; Zalecenie 11/4 dotyczące ograniczenia zrzutów z zakładów celulozowych; Zalecenie 11/5 dotyczące ograniczenia zrzutów pochodzących z zakładów hutnictwa żelaza; Zalecenie 11/6 zawierające podstawowe za- 
Konwencja nie uregulowała problemu odpowiedzialności państw za zanieczyszczenia, co powoduje, że jej skuteczność w praktyce nadal będzie ograniczona.

\section{Współpraca regionalna}

Skupimy uwagę na regionie europejskim oraz Azji i Pacyfiku.

1. Wspólnoty Europejskie wydały w ostatnich dziesięcioleciach ponad 150 dyrektyw i decyzji proekologicznych ${ }^{18}$, co wpłynęło na odpowiednie ukształtowanie ustawodawstw poszczególnych państw członkowskich oraz na ukierunkowanie współpracy regionalnej i nadanie jej większej spójności.

sady zarządzania gospodarką ściekami w przemyśle chemicznym; Zalecenie 11/7 dotyczące monitoringu zanieczyszczeń pochodzących z atmosfery.

18 Do podstawowych uregulowań Wspólnot Europejskich w dziedzinie ochrony środowiska morskiego można zaliczyć następujące akty prawne:

- Decyzja Rady 75/437/EWG. Zanieczyszczenia wód morskich ze źródeł lądowych. Mocą tej decyzji wprowadza się do stosowania Konwencję o zapobieganiu zanieczyszczeń morza ze źródeł lądowych, z 4 czerwca 1974 roku, podpisaną w Paryżu. Ma ona na celu zapobieganie zanieczyszczeniom ze źródeł lądowych północno-wschodnich sfer Oceanu Atlantyckiego i Arktycznego, Morza Północnego, Bałtyckiego oraz Śródziemnego. Rada swą Decyzją 85/613/EWG zatwierdziła programy i działania dotyczące zrzutów rtęci i kadmu, natomiast Decyzją 85/57/WEG - protokół rozszerzający zakres Konwencji o zanieczyszczenia pochodzące $\mathrm{z}$ atmosfery;

- Dyrektywa Rady 76/160/EWG. Jakość wody w kąpieliskach - zarówno morskiej, jak i słodkiej, w której kąpiel jest dozwolona przez państwo członkowskie (lub nie jest zakazana). W Dyrektywie określa się 19 fizycznych, chemicznych i mikrobiologicznych wskaźników jakości wody w kąpieliskach oraz system jej monitoringu przez państwa członkowskie; - Dyrektywa Rady 76/464/EWG. Zrzut substancji niebezpiecznych - przewiduje się eliminację lub zmniejszenie zanieczyszczenia wód śródlądowych, przybrzeżnych i terytorialnych szczególnie niebezpiecznymi substancjami za pomocą oddzielnych "dyrektyw wykonawczych" ustanawiających dopuszczalne wartości emisji substancji niebezpiecznych. Celem dyrektywy jest zapewnienie spójności we wprowadzaniu w życie konwencji międzynarodowych w całej Wspólnocie. Państwa członkowskie muszą ponadto podjąć działania w celu eliminowania zanieczyszczenia substancjami podanych w wykazie I załącznika do dyrektywy oraz dążyć do zmniejszania zanieczyszczenia substancjami wymienionymi w wykazie II załączni$\mathrm{ka}$;

- Decyzja Rady 77/585/EWG. Morze Śródziemne. Przyjęto w niej Konwencję Barcelońską o ochronie Morza Śródziemnego przed zanieczyszczeniem oraz protokół o zapobieganiu zanieczyszczenia Morza Śródziemnego przez zatapianie odpadów ze statków i samolotów;

- Dyrektywa Rady 82/176/EWG. Zrzuty kadmu - określa się wartości dopuszczalne dla różnych sektorów przemysłu oraz wskaźniki jakości w odniesieniu do różnych typów wód; - Dyrektywa Rady 86/280/EWG. Zrzuty substancji niebezpiecznych. Określa wartości dopuszczalne i wskaźniki jakości dla czterochlorku węgla, DDT i pentachlorofenolu w wodach powierzchniowych; 
Wdrożenie do praktyki dyrektyw i rozporządzeń Unii Europejskiej dotyczących bezpieczeństwa morskiego przyczyniło się także do podniesienia poziomu ochrony Morza Bałtyckiego. Sa to m.in. dyrektywa nr 96/98/WE z 1996 r. dotycząca wyposażenia statków; dyrektywa nr 93/ 75/EWG z 1993 r. w sprawie minimalnych wymagań dla statków zawijających do portów Wspólnoty bądź je opuszczających i przewożących towary niebezpieczne lub zanieczyszczające; rozporządzenie rady nr 2978/ 94 z 1994 r. w sprawie wprowadzenia w życie rezolucji IMO o stosowaniu zasad pomiaru pojemności zbiorników balastowych na zbiornikowcach do przewozu oleju; rozporządzenie Komisji nr 179/98/WE z 1998 r. $\mathrm{w}$ sprawie bezpiecznego zarządzania promami $\mathrm{i}$ inne.

Dyrektywa z 27 czerwca 2002 r. zobowiązuje wszystkie państwa członkowskie do wydzielenia odpowiednich stref, w których mogłyby schronić się statki w wypadku awarii lub innego poważnego problemu zagrażającemu bezpieczeństwu środowiska morskiego obszaru Unii Europejskiej. Każde państwo ma obowiązek przedstawienia Komisji Europejskiej listy takich stref.

W listopadzie 2002 r. uległ katastrofie płynący pod banderą Bahamów tankowiec "Pregige”, który zatonął u wybrzeży Hiszpanii. Wyciekło z niego ponad 17 tysięcy ton oleju, i jak szacuje się, do roku 2026 wypłynie jeszcze około 50 ton tej toksycznej substancji. Ponad $900 \mathrm{~km}$ wybrzeża Hiszpanii i Francji zostało w różnym stopniu zanieczyszczone, zaś 4 tysiące hiszpańskich rybaków nie może podjąć pracy z powodu wprowadzonego zakazu połowów.

Komisja Europejska 3 grudnia 2002 r. opublikowała "czarną listę" 66 niebezpiecznych statków, które miałyby mieć zakaz wpływania na wody krajów Unii. Znajdują się na niej jednostki z 13 państw, z czego 26 pochodzi z Turcji, 12 z St. Vincent i Grenadynów, 9 z Kambodży, po 3 z Algierii, Panamy, Wysp Św. Tomasza i Książęcej, po 2 z Boliwii, Egiptu i Rumunii, a po 1 z Hondurasu, Libanu, Maroka i Syrii. Komisja zapropono-

- Decyzja Rady 86/85/EWG. Rozlewy olejowe. Ustanowiono w niej system informacyjny funkcjonujący pod auspicjami Komisji. Obejmuje pięć dziedzin działalności związanych ze zwalczaniem rozlewów na morzu lub większych wodach śródlądowych, plany zwalczania zanieczyszczeń spowodowanych rozlewami olejów na morzu, inwentaryzację środków stosowanych do zwalczania zanieczyszczenia olejami wód morskich;

- Dyrektywa Rady 93/75/EWG. Minimalne wymagania dla statków zdążających do portów Wspólnoty lub je opuszczających i przewożących towary niebezpieczne lub zanieczyszczające. Recypuje postanowienia Konwencji MARPOL, nakładające obowiązek przedstawienia kompetentnym organom władz portowych informacji o charakterze i rozmieszczeniu towarów niebezpiecznych i zanieczyszczających na statkach;

- Decyzja Komisji 93/550/EWG z dnia 21 lutego 1994 r. w sprawie przystąpienia Wspólnoty do Konwencji w sprawie ochrony środowiska morskiego obszaru Morza Baltyckiego z 1992 r. (Konwencja Helsińska). 
wała także wprowadzenie natychmiastowego zakazu przewozu olejów przez tankowce jednokadłubowe.

Prawne środki ochrony i zachowania środowiska morskiego są jedną z prób uratowania mórz i oceanów. Tworzone są również morskie rezerwaty przyrody, ale nie są one wystarczająco skutecznym sposobem na ochronę morskiego środowiska naturalnego. Rezerwaty takie powstały lub są tworzone w Nowej Zelandii, na Pacyfiku w pobliżu Hawai, u wybrzeży Ameryki Północnej i Europy.

2. Współpraca morska w regionie Azji i Pacyfiku ${ }^{19}$ przyczynia się także do ochrony środowiska.

$\mathrm{W}$ rejonie tym na stan środowiska morskiego wpływ wywiera przede wszystkim żegluga.

Znaczenie żeglugi i jej bezpieczeństwa oraz dostępu do linii komunikacyjnych w regionie Azji i Pacyfiku wzrasta wraz z wielkim strumieniem handlu przyczyniającym się do rozwoju ekonomicznego całego obszaru. Najważniejsze szlaki znajdują się na Morzu Południowochińskim oraz przechodzą przez trzy cieśniny:

a) Malakka, pomiędzy Malezją i Sumatrą, gdzie przepływają mniejsze jednostki z powodu jej płytkości i niewielkiej szerokości do półtorej mili,

b) Sundajską, między Sumatrą a Jawą,

c) Lombok, między Bali a wyspą Lombok, szczególnie nadającą się dla tankowców.

Przepływa tamtędy ponad połowa wszystkich statków handlowych, co skutkuje wymianą na sumę jednego biliona dolarów rocznie, tj. 20\% produktu krajowego brutto tego regionu.

W związku ze wzrostem handlu na wspomnianym obszarze współpraca regionalna w celu zachowania środowiska i bezpieczeństwa mórz staje się coraz ważniejsza. Należy wyróżnić takie podstawowe dziedziny kooperacji jak: udział państw regionu w najważniejszych konwencjach IMO (Międzynarodowej Organizacji Morskiej); Memorandum Tokijskie w sprawie porozumienia o kontroli portów - MOU, współpracę regionalną w poszukiwaniach i ratownictwie - SAR, współpracę w sprawie katastrof morskich.

IMO - jak wiadomo - powołano jako agendę wyspecjalizowaną ONZ, $\mathrm{z}$ siedzibą w Londynie, skupiającą obecnie około 160 państw. Zajmuje się ona bezpieczeństwem żeglugi i ochroną środowiska. Organizacja ta wypracowała kilkadziesiąt konwencji, z których najważniejsze to:

- SOLAS 1974 o bezpieczeństwie życia na morzu, do której należą wszystkie państwa regionu z wyjątkiem Laosu i Mongolii (nie mają dostępu do morza),

19 Zob. Canberra Papers on Strategy and Defence, 1998, No 132 (artykuł Stanley'a B.A. Weeksa). 
- COLREGS 1972 o międzynarodowych uregulowaniach zapobiegających kolizjom morskim,

- STCW 1978 o standardach szkoleń, certyfikacji i nadzoru przewoźników,

- SAR 1979 o poszukiwaniach i ratownictwie morskim. Konwencja ta ma małą liczbę ratyfikacji.

Większość państw regionu podpisała te konwencje, z wyjątkiem Konwencji SAR. Stwarza to podstawy szerokiej współpracy. Memorandum Tokijskie z 1993 roku zakłada natomiast stworzenie regionalnego systemu wzajemnej współpracy przy inspekcjach statków w celu weryfikacji ich zgodności z międzynarodowymi standardami bezpieczeństwa oraz harmonizację procedur kontrolnych w portach. Konwencja SAR 1979 o współpracy w dziedzinie poszukiwań i ratownictwa, jest w pełni zgodna z szeregiem inicjatyw regionalnych, dwu- i wielostronnych. W sprawy te zaangażowane jest Forum Regionalne ASEAN, które sponsoruje międzynarodowe spotkania (Honolulu 96 i Singapur 97) na temat współpracy i ćwiczeń. Spotkania te wypracowały Deklarację o Współpracy przy Poszukiwaniach i Ratownictwie i zachęciły do kontynuacji prac na poziomie technicznym. SAR - to także część programu współpracy morskiej na forum Western Pacific Naval Symposium, gdzie co dwa lata spotykają się szefowie marynarek, zachęcając do stabilności i współpracy regionalnej. Wspólnie organizowane są ćwiczenia, z udziałem nawet dawnych antagonistów, co zmierza do zacieśnienia więzi i współpracy regionalnej.

Współpraca w sytuacji katastrof morskich wynika z zagrożenia regionu tajfunami, tsunami i innymi zjawiskami. Dotyczy ona pomocy humanitarnej i likwidacji szkód. Równocześnie w Azjatyckim Instytucie Technologicznym w Bangkoku powstało Centrum Przygotowań na Wypadek Katastrof, udzielające potrzebnych informacji i wspierające współpracę.

Innym ważnym zagadnieniem jest nielegalne rybołówstwo. Zauważalny jest brak wystarczającej współpracy wielostronnej, takiej jaka występuje na południowym Pacyfiku, gdzie działają np.: Forum Agencji Rybackich (założone w 1979 r.) i Traktat z Niue 1993 r. o nadzorze rybołówstwa i wykonywaniu prawa połowów na południowym Pacyfiku. W Azji Południowo-Wschodniej istnieją tylko pojedyncze umowy dwustronne, jak na przykład między Wietnamem i Tajlandią z 1997 r. o granicy morskiej w Zatoce Syjamskiej, które jest pierwszym porozumieniem o delimitacji stref ekonomicznych od 1982 r. Przewidziano wspólne patrole, wymianę informacji o naruszeniach prawa, dostarczanie informacji rybakom na temat prawa i innych regulacji oraz budowę zaufania i współpracę ekonomiczną w zakresie rybołówstwa. Inną tego typu umowę zawarły Japonia i Rosja.

Istotne znaczenie dla ochrony środowiska morskiego, $\mathrm{w}$ tym regionie ma konwencja o prawie morza z 1982 r. Przewiduje ona bowiem współ- 
pracę państw w wykonywaniu ich praw i obowiązków. Podobne sformułowania wynikają z odpowiednich przepisów rozdziału 17. w Agendzie 21. Widoczne jest pokrywanie się kompetencji zaangażowanych organizacji. Istnieje sieć współpracy, na podstawie takich konwencji jak: o zapobieganiu zanieczyszczeniom ze statków z 1973 r.; o gotowości, przeciwdziałaniu i współpracy na wypadek zanieczyszczenia olejami z 1990 r.; o ograniczaniu wyrzucania niebezpiecznych odpadów z 1972 r.; o ustanowieniu międzynarodowego funduszu kompensacyjnego za szkody wynikłe z zanieczyszczenia olejami z $1971 \mathrm{r}$.

Są to konwencje międzynarodowe powszechne, nie dotyczące bezpośrednio omawianego regionu, jednak $\mathrm{w}$ przypadku ich ratyfikacji staną się prawem powszechnie obowiązującym. Liczba ratyfikacji tych aktów jest jednak nadal niewielka.

W Azji Południowo-Wschodniej rozwija się współpraca naukowa i monitoring w ramach Planu Działania w Regionie Północno-Zachodniego Pacyfiku (NOWPAP) opracowanego przez UNEP, który przewiduje stworzenie bazy informacji, integrację planowania i ustanowienie prawnych ram współpracy. Poza tym istnieje wiele programów o dublujących się kompetencjach, takich jak: Program Regionalny o zapobieganiu i postępowaniu w razie zanieczyszczeń (sponsorowany przez UNDP i IMO), w ramach którego rozwija się monitoring i pomoc techniczną, kładzie się nacisk na koordynację i budowanie zdolności regionalnych, a także na konserwację zasobów morskich. Innym przykładem może być program wypracowany przez ASEAN o podobnych założeniach.

Współpraca regionalna $\mathrm{w}$ regionie Azji i Pacyfiku cechuje się wykształceniem ram prawnych na kanwie konwencji międzynarodowych. Różny stopień przynależności do nich, a także miejscowe uwarunkowania polityczne nie zawsze jednak pozwalają odpowiednio je wykorzystać, przez co kształtowanie tej współpracy wymaga wielu wysiłków, aby mogła przynosić spodziewane wyniki.

\section{Uwagi końcowe}

Przedstawiona w ogólnym zarysie międzynarodowa ochrona środowiska morskiego może być postrzegana jako pewien system regulacji obejmujących zasady i formy współpracy $w$ tej dziedzinie. Jest ona niewątpliwie zgodna z głównymi kierunkami proekologicznej strategii nakreślonej przez społeczność międzynarodową i stosowanymi podstawowymi instrumentami działania na rzecz ochrony środowiska naturalnego w skali regionalnej i globalnej z udziałem systemu ONZ. Współdziałają z nim także liczne organizacje międzyrządowe i pozarządowe, także regionalne. 
W ochronie środowiska morskiego ma znaczący udział kształtujące się międzynarodowe prawo ochrony środowiska. Obecnie jest ono znacznie szersze i bardziej zróżnicowane niż na początku minionego stulecia, kiedy to zajmowało się ograniczoną ochroną niektórych gatunków fauny i flory. Głównym zadaniem tego prawa jest regulowanie stosunków międzynarodowych związanych z problematyką ochrony środowiska naturalnego. Skala przedmiotu regulacji jest obecnie dość rozległa, a wśród międzynarodowych inicjatyw i działań istotne miejsce zajmują problemy dotyczące tzw. szkód transgranicznych, spowodowanych różnymi zanieczyszczeniami. Coraz większego znaczenia nabierają szkody spowodowane wypadkami instalacji nuklearnych, wypadkami z udziałem obiektów kosmicznych oraz katastrofami morskimi, zwłaszcza z udziałem tankowców. Tworzenie i poszukiwanie nowych, bardziej adekwatnych i skuteczniejszych rozwiązań jest procesem długotrwałym. Prawo morza i prawo ochrony środowiska ma poprzez odpowiednio zinstytucjonalizowane formy działania proekologicznego zapewniać odpowiednie warunki globalnego bezpieczeństwa ekologicznego ludzkości, zwłaszcza w takich dziedzinach jak bezpieczeństwo klimatyczne, bezpieczeństwo biologiczne i chemiczne oraz nuklearne.

\section{The marine environment protection: Topical issues" system of international rules and principles, ways and means of co-operation. (Ground plane)}

\section{SUMMARY}

The author discusses: main sources of marine environment pollution and measures to prevent, reduce and control to ensure effective protection, and the co-operation on a global or regional basis. Legal measures have been included for enforcement with respect to merine environment from harmful effects which may arise by pollution from land-based sources, pollution by dumping, pollution from vessels and pollution from activities in the Area. Enforcement copmrises proper measures by flag and port States as well as coastal States.

As topical issues have been discussed rules and principles regulated by the United Nations Convention on the Law of the Sea (1982) - i.e. uses of the seas and oceans, the conservation of their living resources" and the study, protection and preservation of the marine evironment. Also same selected matters of the marine environment protection and regional co-operation in Europe as well as in Asia and Pacific rims have been included. 